\title{
Towards EU 2020: An Outlook of SECA Regulations Implementation in the BSR
}

\author{
Eunice Omolola Olaniyi \\ Department of Business Administration, \\ Tallinn University of Technology \\ Akadeemia tee 3 , \\ Tallinn 12618, Estonia \\ E-mail: eunice.olaniyi@ttu.ee
}

Abstract: The clean shipping concept emerged in a bid to make maritime transportation green and environmentally friendly. This mandate is being accomplished through improved conducts, actions and technology in the maritime industry. One of such measures was the creation of the Sulphur Emission Control Areas (SECA) in 2005 and 2012 to reduce the rate of sulphur emissions from shipping. Sustainable growth - an EU 2020 priority -is strategically linked to the SECA regulation in that it promotes resource efficiency, greener environment and a competitive economy.

Thus, the International Maritime Organisation (IMO) and, as adopted by the European Parliament (EP), SECA regulation stipulated that from 2015 all ships in SECA are under the obligation to use low sulphur marine fuel that must not exceed 0.1\% (IMO, 2011). This regulation has incited rigorous arguments on the economic disadvantage it would subject affected maritime stakeholders who are made to comply with stringent regulation their counterparts in non-SECA are not subjected to.

Two years of $0.1 \%$ sulphur regulations have witnessed many changes in the maritime industry and most of the first responses were realised with vessels that ply along the Baltic Sea. This work presents an account of European maritime industry's approaches towards SECA regulations and the stakeholders' thoughts on the economic impact of SECA. This contribution brings a clearer picture to the status quo as well as highlighting a needed future focus. 
Keywords: clean shipping, emission reduction, EnviSuM project, EU 2020, institutionalism, SECA

\section{Introduction}

Shipping is considered environmentally friendly because the cargo conveyed on a tonne mile basis appears insignificant when measured and compared to the mass and space of water (Jiang, Kronbak \& Christensen, 2014). However, despite this, ships are the major source of pollutants such as carbon oxides $\left(\mathrm{CO}_{2}\right)$, sulphur oxides (SOx), ozone depleting substances (ODS), volatile organic compounds (VOC) and (nitrogen oxide (NOx) emissions (Wiśnicki et al., 2014). Even though most of the emissions from the ships are deposited into the deep sea, these emissions are still responsible for acidification and eutrophication, and especially for the negative impact on the environment (Airclim, 2011; Sheba, 2014). After a prolonged exposure, they form poisonous compounds that infiltrate the lungs and poison the blood causing premature death from inflammation, heart and lungs failure (Alcamo et al., 1987; Corbett \& Farrell, 2002; Cullinane \& Bergqvist, 2014). While shipping is compared to other modes of transportation, it appeared better in terms of an amount of $\mathrm{CO}_{2}$ emissions (Holmgren et al., 2014), however, the production of sulphur oxides ( $\mathrm{SOx}$ ) and nitrogen oxides ( $\mathrm{NOx}$ ) emissions from shipping activities is greater in comparison to land transportation (Panagakos, 2014).

The priority of clean shipping is to make maritime transport greener (Stipa, 2013). Integrated clean shipping strategy zooms on three areas. The ship that can be received in all ports with near to nil target emissions, ports that are competent and equipped with environmentally-friendly facilities and at the same time can offer encouraging incentives to expedite clean shipping, and lastly, cargo with appropriate corporate footprint and owners that embrace environmentally conscious decisions (NSF, 2008). These efforts are synchronised with the Europe 2020 objective of sustainable growth (Prause, 2014a). According to EU (2010), they include the following:

- 'Smart growth' or creating an economy-based knowledge and innovation;

- 'Sustainable progress' or encouraging a resourceful, competent, greener and more competitive economy;

- 'Inclusive growth' or nurturing a high-employment economy that will deliver social and territorial cohesion. 
Green growth, social sustainability and energy efficiency are the core to achieving growth sustainability (Prause \& Hunke, 2014). Many efforts are seen in the development and expansion of greener initiatives around Europe. Examples are in the public transport system, reductions in fossil and fuel consumption, waste management, district heating, climate change awareness, reduction of greenhouse gas emissions by $20-30 \%$ and green infrastructure initiatives (Hunke \& Prause, 2013; Prause, 2014b; Nabielek, Hamers \& Evers, 2016). There is a high focus especially on the creation of about $20 \%$ of the EU energy demands from renewables and increased energy productivity by $20 \%$ before 2020 (EU, 2012).

As a result, international legislation on shipping was strengthened and shipping is no longer allowed as usual. Particularly, this policy focuses on a reduction of sulphur in ship fuels, which is expressed in terms of $\% \mathrm{~m} / \mathrm{m}$ (mass). Thus in May 2005, the Sulphur Emission Control Area (SECA) was created to curtail airborne emissions from ships. In that, ships trading in designated emission control areas will have to use on-board fuel oil with a sulphur content of no more than $0.1 \% \mathrm{~m} / \mathrm{m}$ from 1 January 2015 (IMO, 2015). The SECA area embodies about $0.3 \%$ of the world's waters (Notteboom, 2010).

Panagakos (2014) emphasised the importance of fortified regulations and environmental awareness for the stimulation of clean shipping and at the same time warned about the magnitude of the costs for the maritime industry. If Panagakos' deductions are true, the repercussions of the SECA regulations on the maritime sector stakeholders can be linked directly or indirectly to the investment decisions that will ensue in the compliance actions. Normally, the affected companies respond to regulations by changing their strategies for the innovation process and activities such as research and development, expansion, equipment upgrade (Olaniyi \& Viirmäe, 2016). In their studies, Hämäläinen (2015) and Hämäläinen, Hilmola \& Tolli (2016), showed concerns on the implication of the SECA regulation that it could lead to a modal backshift from sea to the road causing more road pollution and congestion, thereby conflicting with other land regulations. Other concerns were for reduced revenue for export companies whose supply chain is mainly marine based (AirClim, 2011; Hämäläinen et al., 2016).

In 2015, the EU officially approved EnviSuM-Environmental Impact of Low emission Shipping Measurements and Modelling Strategies project - to research and evaluate the technical efficiency and the socio-economic impact of clean shipping solutions in the BSR in the framework of the BSR Interreg Programme. The EnviSuM plans to deliver verified results on the effectiveness of the various 
clean shipping solutions and offer beneficial references for the environment and health of the BSR population. It also plans to promote economic development in the maritime sector. Thus, this study is a part of the current EnviSuM project studies on the economic consequences of the Sulphur Emission Control Area (SECA) regulations on maritime stakeholders in the BSR. The aim of this work is to study the BSR maritime compliance activities concerning reduction of sulphur emission. It also studies collective stakeholders' assessments on how the SECA regulations have affected or will affect their businesses and the BSR. The research questions addressing this subject are: (1) How has the SECA regulation influenced the maritime sector in the BSR? (2) How has the innovation that stemmed from the SECA regulations compliance influence blue growth and clean shipping activities in the BSR? and (3) What are the stakeholders' reactions to these impacts?

Innovation, in this study, is 'incremental innovation'-improving already existing products by making them better, faster, and cheaper; 'process and business model innovation'-implementation of a new/improved products and services that occur through the cross-sectorial blend of technologies, design and business simulations consisting of unique incidents that lead to beneficial change as described by Olaniyi and Prause (2016).

The first and the second question will be answered by using the qualitative analysis of interviews and focus group sessions, while the third question will be tackled by using a survey analysis. This contribution is aimed at improving the integration of new knowledge that will provide new systems for cleaner and more cost-effective shipping for the maritime sector.

The structure of the work is as follows: Section II discusses the theoretical framework. Section III describes the methodology. Section IV highlights the various SECA directive compliance activities observed in the BSR as well as its economic influence on maritime businesses environment and the BSR. Section $\mathrm{V}$ discusses the implications of the results and Section VI concludes. 


\section{Theoretical framework}

\subsection{Institutionalism and its influence on industrial behavioural pattern}

Organisations are subjected to and dependent on environmental influences (often referred to as institutional forces) and one of such influences are regulations (Furusten, 2013). Regulations force organisations to conform in order to meet the criteria for corporate citizenship (Gardberg \& Fombrun, 2006). Institutional theory (mostly used for the adaptation of organisational practices) postulates that organisational structures are not spontaneous nor driven only by competition or wanting to be effective but are mostly influenced by the rules, norms and demand of their environment and stakeholders (Meyer \& Rowan, 1977; DiMaggio \& Powell, 1983; Dacin, Goodstein \& Scott, 2002). Institutional theory gained popularity because it was able to explain the complex assessment of why organisations change their character and influence progressively (Dacin et al., 2002), and provides an explanation for the parallelism that is common between them and their environments which emphasise that organisations are structural reflections of socially created realities (Meyer \& Rowan, 1977).

The core of the institutional viewpoint is that normative pressures, whether external or internal, usually influence organisations. Even more so, when organisations are within the same environment they are sometimes obliged to practice similar activities (Peters, 2000). This mostly happens when organisations are trying to conform to constitutional rules in their bid to be legitimate and successful in the environment they find themselves. Sometimes, members of a particular industry do not have choices that can be modified through their membership but have to accept predetermined choices (also called norms) that cannot be changed by their association. This gives an explanation concerning the predictive nature of organisations (Martin \& Frost, 1996), in which conformity ensures legitimacy and institutional initiatives produce safety nets and opportunities that cushion and reduce organisational risks (Gardberg \& Fombrun, 2006).

A "norm" is a rule created by a group of people in a particular environment with some degree of binding authority over the same set of people (Meyer, 2008). These changes are mostly about organisations responding to the challenges of the existence of the institutions governed by their environment (Dacin et al., 2002). In some cases, conformity comes as result of a direct mandate from the state (DiMaggio \& Powell, 1983). Legitimacy activities can facilitate the opportunity for an organisation to distinguish itself and construct local advantages (Kostova $\&$ Roth, 2002). An example of this is an environmental regulation like the 
SECA regulation. While there are common rules across boards, organisational conformity to the institutional atmosphere give room for positive appraisal and increases survival chances (Zucker, 1987).

In most modern organisation theories, organisations try to differentiate themselves with their structures. However, structural change in organisations is not so much driven by the mentioned factors as they are by institutionalism, which leads to homogeneity (DiMaggio \& Powell, 1983). Institutional theory proposed a correlated description for homogeneity in organisations known as 'institutional isomorphism' (Lieberman \& Asaba, 2006), as a coercing process that forces a specific unit of population to bear resemblance to other units that are in the same regular conditions which make them competitive or normative (DiMaggio \& Powell, 1983). As such, organisational features are modified towards a growing compatibility with the norm. Sometimes these practices evolve over time due to shared knowledge ('mimetic isomorphism'), on the other hand, sometimes it is due to some social realities that are enforced by the law, stakeholders or public opinions thus becoming legitimate and institutionalised ('coercive isomorphism') (Meyer \& Rowan, 1977; DiMaggio \& Powell, 1983; Dacin et al., 2002). In some other cases, organisations respond to what they perceive as suitable and appropriate for the environment where they are ('normative isomorphism') (DiMaggio \& Powell, 1983).

To study the influence of the institutional environment on the organisation in another methodical way, Kostova and Roth (2002) introduced the institutional profile theory and called them issue-specific pillars. These are regulatory, cognitive, and normative institutions, which are usually influenced by different motivation or isomorphism. Defining the three pillars, Kostova and Roth explained that the regulatory pillar mirrors the existing regulations and rules in a national environment and stimulates a particular set of attitudes. The cognitive pillar reflects the stereotypes used in a given country while normative pillars show their values and beliefs. Affirming Zucker's (1987) summation that in an institutionalised context, organisations are pressured to become increasingly similar due to environmental control and that some of the indicators of 'institutional environment' reflect pressures that are external to the organisation, such as the laws and regulations created by the states or professional authorities.

One the other hand, this particular part of the neoclassical paradigm of the institutional theory also focuses on the study of how regulations as an institutional structure can cause organisations to respond differently to the same set of simulations (Reynolds, 1981). In compliance, while organisations are expected to respond in a certain way to meet regulatory demands, there is no guarantee 
that the whole system will do so in similar actions to achieve legitimacy. Even though the existence of common legal conditions affects many aspects of an organisational activity and decisions, most imitations seen in organisational structures are because of the fact that there are no other set choices to select from (DiMaggio \& Powell, 1983). Hence, the selection is usually subject to the evaluation of individual organisational interests and perceived benefit (Reynolds, 1981).

When the SECA directive was introduced, maritime stakeholders and related organisations had to comply in order to be legal to run shipping businesses in the SECAs. They had few compliance options to choose from and a lot of them had to carefully make their choice based on perceived benefit, acceptable risk and costs of investments. In new institutional economics, transaction costs (compliance costs) are expensive with the tendency to interfere with effective productivity (Olaniyi \& Viirmäe, 2017). Thus, compliance choices are strategic for most companies.

\subsection{Sulphur emissions regulations and shipping on the Baltic Sea}

To ensure synchronisation with other international law as well as for improved implementation, the Directive 1999/32/EC was enacted to regulate sulphur emissions from ships and was amended by Directive 2005/33/EC in Annex VI of the International Convention for the Prevention of Pollution from Ships (MARPOL 73/78). The law restricts the sulphur content of the marine fuel used in the designated sea areas to $1.5 \% \mathrm{~m} / \mathrm{m}$, further to $1.0 \%$ by 1 July 2010 and later to $0.1 \% \mathrm{w} / \mathrm{w}$ by 1 January 2015 (IMO, 2008; 2009; 2013). The Baltic Sea Region (BSR) was the first water designated as SECA in 2006 and in 2007, the North Sea Area and the English Channel (Nugraha, 2009). In December 2016, China also designated three emission control areas in its states. These are the Pearl River Delta, the Yangtze River Delta, and the Bohai Sea in China waters (North, 2016). Recently, in the MEPC 70th meeting, the global sulphur cap in non-SECA of $3.5 \%$ was reduced to $0.5 \%$, effective from January 2020 (IMO, 2016).

In MARPOL 73/78, the BSR is described as "the Baltic water with the Gulf of Bothnia, the Gulf of Finland and the entrance to Baltic Sea bounded by the parallel of the Skaw in the Skagerrak at $57^{\circ} 44^{\prime} .8$ N". This is approximately about $415,000 \mathrm{~km}^{2}$ and shallow. It is known as the major brackish water in the world, measuring $53 \mathrm{~m}$ in depth and having a narrow canal that makes navigation challenging for cruising ships (Helcom, 2012). Because a significant share of the world's marine cargo freight takes place on it, it is subjected to 
rigorous shipping activities (Breitzmann, Möller \& Wenske, 2013) making it the most heavily plied seas in the world up to about $15 \%$ (Daduna, Hunke \& Prause, 2012). All these activities make the Baltic Sea vulnerable to substantial pollution whose aggregate effect will be harmful (Breitzmann et al., 2013). Substantial foreign trade freights are routed through the Baltic Sea ports of Finland, Sweden, Denmark, Poland, Russia, Germany, Estonia, Latvia and Lithuania and as a result of steady growth witnessed in the economic sector of the BSR, escalated trade freights on it are foreseeable in the future (Helcom, 2012; Daduna \& Prause, 2016).

The SECA regulations, as other regulations, typically are expected to increase the costs of shipping operations, especially for ships that ply SECAs regularly. There are concerns that the SECAs might alter the competitiveness of European industry in global markets and international trade or even disrupt the level playing field of globally operating industries (Korhonen et al., 2015), and the delivery of economic growth (COMPASS, 2010). Already, there was the anticipation of about 25-35\% increase per tonne freight (Notteboom, 2010). The 2020 global sulphur cap of $0.5 \%$ is also speculated to increase the costs of container ship to about 4-13\%. COMPASS (2010) hypothesised that global sulphur cap could result in an increase in the overall price of fuel by 2020. This speculation could lead to some industries relocating for "better" business conditions. For instance, Hämäläinen et al. (2016) stated that companies like the paper machine and mill in Finland might be facing closure due to the SECA directive, because of cost challenges and may have to relocate the bulk paper production closer to the markets in Central Europe. However, OECD/ITF (2016) refuted the impact of the sulphur emission regulation on global trade flows and reported that it has been negligible.

A lot of authors already have extensively evaluated the different options for the SECA regulations compliance (i.e. Notteboom, 2010; Wiśnicki et al., 2014; Jiang et al., 2014; Nugraha, 2009; Brynolf et al., 2014; Bergqvist, Turesson \& Weddmark, 2015; OECD/ITF 2016), which will be explained briefly in the next paragraphs.

The easiest option to reduce sulphur emission is to change the use of the usual marine heavy fuel oil (HFO) to cleaner and lighter distillates that emit little waste after combustion such as the Marine Gas Oil (MGO) and Marine Diesel Oil MDO (Farrell et al., 2002; Brynolf et al., 2014; Wiśnicki et al., 2014). Fuel switching option is subject to the unpredictable trends in fuel prices because of the volatility prevalent in the fuel market (Jiang et al., 2014; Hämäläinen et al., 2016).The second option is the use of alternative fuel such as liquefied natural 
gas (LNG), biogas, biodiesel, ethanol, methanol, coal, nuclear power, wind, solar panels, and hydrogen cells. The use of LNG is arguably the most politically supported option. Natural gas has long been widely used in land industry for heating and transportation purposes. It is naturally low in sulphur and satisfies the new sulphur regulation requirements (Jiang et al., 2014). The discussions on LNG are popular because ship engines that operate on it emit almost zero $\mathrm{SO}_{2}$. Not only this, the emissions of NOx and PM are also drastically reduced by $80 \%$ or more (AirClim, 2011). It is more convenient for vessels trading between fixed ports where LNG fuel is available to use LNG as marine fuel than for large ships that need deep sea shipping (Wiśnicki et al., 2014). Bergqvist et al. (2015) explained that keeping LNG in liquid form requires the gas to be below its boiling point, which is $163^{\circ} \mathrm{C}$ kept under pressure and requires large tanks installed either above the deck or inside the ship. As expected, the tanks will take about three times or more space than other fuel tanks. This is one of the disadvantages of using LNG. It is rather expensive to convert old vessels to LNG, so most LNG-powered vessels are newly built (Bergqvist et al., 2015).

Another popular option is the use of the scrubber, an abatement technology that removes sulphur deposit from the ship exhaust and permits the use of the cheaper HFO (Concawe, 2013). There are two types of scrubber-the dry and the wet scrubbers. The wet scrubber is categorised into three types: the open loop, the closed loop and the hybrid system scrubbers. One of the drawbacks common with the use of the scrubbers, mostly the wet scrubbers is how or where the acidic wash water is discharged. Another is that the discharged sludge must be kept in storage on board until the ships berths giving the ship extra weight while cruising (Jiang et al., 2014). The cost of the retrofit is around 2-4 million euros, subject to the age and the size of the ship. A scrubber has a lifespan of 10-15 years (Brynolf et al., 2014) and 3-5 years of payback period (Atari \& Prause, 2017). The scrubber can be installed on both new and old ships (Bergqvist et al., 2015).

A special measure to reduce ship emissions in the ports is the use of onshore power supply (OPS), a land-based power grid connection when vessels berth in ports. This is a corresponding EU directive that enforces shore-side electricity supply infrastructure to be installed in all TEN-T Core network ports and other ports by 31 December 2025 (Directive 2014/94/EU). Usually, scrubbers are fitted on the main engines, at berth ships usually shut off the main engine and leave the auxiliary engines running to generate electricity. When the onshore power is used, there is a reduction in the emissions from ships. With various ports installation facilities coming up, ship-owners are being encouraged to adapt their ships to using onshore power when berthed (OECD/ITF, 2016). This 
option has become a necessity for ships who have a great need for electricity at berth (Ecofys, 2015; OECD/ITF, 2016).

\section{Methodology}

\subsection{Instruments and materials}

All data collection activities took place between May 2016 and May 2017. The first and second research questions were answered by examining previous studies and published reports on SECA. Furthermore, face-to-face structured and semi-structured experts' interviews were made across the BSR. Where faceto-face interviews were impossible, phone calls and Skype videos were made. The interview lasted between 1 and 2 hours. 39 interviews were made. Other study instruments were the BSR maritime experts' focus group meetings in the frame of EnviSuM learning café.

The third research question was investigated through a survey study. The survey was conducted to assess BSR maritime experts' perceptions on the economic effect of SECA regulations. A pilot survey was first conducted according to Easterby, Thorpe \& Jackson (2012) to create content validity, clarity and suitability. EnviSuM partners from Germany, Estonia, Finland, Denmark, Norway and Poland were part of this activity. 509 surveys were sent out through a collective effort from all EnviSuM partners across the BSR, collecting 122 respondents, representing a cross-section of maritime experts at the management level. The low responses from the survey were triangulated with previous results from interviews and focus group meetings according to Leary (2009).

\subsection{Sample}

Top management executives were targeted because they make most of the economic and investment decisions. The stakeholders were divided into 5 categories and catalogued according to how directly impacted they are from SECA regulations. Table 1 depicts this categorisation where a 3-star level indicates high priority, 2 stars indicate medium priority and a 1-star level means low priority. Using this, categories 1,2 and 3 consisting of Shipping companies/ Ship operators/Ship owners, Ports and Ship Suppliers became the major focus of this data analysis. 
Table 1. SECA Maritime Stakeholders Priority Index

\begin{tabular}{|c|c|c|}
\hline Category & Maritime Stakeholders & $\begin{array}{l}\text { Order } \\
\text { of } \\
\text { Impact }\end{array}$ \\
\hline Category 1 & Shipping companies/Ship operators/Ship owners & 3 stars \\
\hline Category 2 & Ports & 3 stars \\
\hline Category 3 & Ship Suppliers (maritime equipment and services) & 2 stars \\
\hline Category 4 & $\begin{array}{l}\text { Port authority, Non-governmental organisation (NGO) } \\
\text { Public sector (Ministry, Municipal, Government } \\
\text { agency, Education, Research), Police/customs }\end{array}$ & 1 star \\
\hline Category 5 & $\begin{array}{l}\text { Shippers (Logistics service providers, Production and } \\
\text { Trading, Real Estates/Facilities managers) }\end{array}$ & 1 star \\
\hline
\end{tabular}

\subsection{Measurement and analysis}

Analysis of this research encompasses 2 studies:

Study 1: The analysis was based on interviews, the focus group meetings and document reviews. A descriptive analysis of the interview data according to Yin (1989) was used to highlight SECA related activities and their core patterns in the maritime community in the BSR.

Study 2: The analysis was based on the survey. Statistical software was used to analyse and interpret the perceived impact of SECA regulations on maritime business activities in the BSR. The first part of the analysis was conducted to acquire data on the stakeholders' general perception of SECA. It included maritime sector-specific questions on their SECA related activities, SECA implementation benefits, gaps, and maritime stakeholders' future expectations. In the second part, the survey analysis included a 10-factor questionnaire to measure the economic impact of SECA regulation from the viewpoint of the maritime stakeholders. The question, as elucidated in Table 2, covered the economic impact of SECA on blue growth, costs, pricing, own company development, innovation, FDI, cargo flows, modal split and branding of the BSR.

A 5-point summative rating scales from -2 to +2 , the degree to which the impact is very negative to very positive, was used to evaluate each factor. The mean score of the answers obtained regarding the impact of SECA regulations indicates the degree to which the questionnaire relates to the underlying overall 
perspectives. Kerlinger (1986) discussed some of the weaknesses of the rating scales and one of them is their measurements, as they are perceived to be "too easy" to construct for them to be impactful. This issue was addressed through the pilot survey and interviews with various EnviSuM partners from the different maritime sector where the survey was designed to allow open comments to each question. This technique is similar to what Fowler (1995, p. 131) called "the field pre-test with observation". Item-specific comments were tracked and analysed and wordings were improved as needed.

Table 2. Factor dimension of the economic impact of SECA regulations

What is the impact of SECA regulations on the maritime businesses and the BSR?

Overall economic impact on the BSR

Impact on blue growth in the BSR

Impact on your product/service costs

Impact on your pricing

Economic impact on your company development

Impact on innovation of maritime sector in the BSR

Impact on attractiveness of the BSR for foreign direct investment (FDI)

Change of cargo flows within Europe

Change on transport modal split within the BSR

Reputation/branding of the BSR

Note: $n$ of data $=122$

\section{Results}

\subsection{Study 1: SECA regulations compliance activities}

The results from the experts' interviews, focus group meetings, and reports reviews revealed the following:

\subsubsection{Compliance activities by ship owners}

The use of low sulphur content fuel: Because of the uncertainties that surround the fuel price and SECA regulations, most ship owners at the moment are favourably disposed towards the use of fuel distillates such as MGO and MDO. 
Fortunately, a new fuel type called the ultra-low sulphur fuel oil (ULSFO), a hybrid fuel of different refinery streams with a higher viscosity and lower volatility to the MGO has been developed and is gaining popularity as a cheaper source of marine fuel since 2014. This is a major innovation stemming from the need for a cheaper alternative from the heavy investment that is needed for the scrubber and the LNG options. By the end of 2016, there was approximate 200,000mt Amsterdam-Rotterdam-Antwerp monthly supply that is projected to increase above $350,000 \mathrm{mt} / \mathrm{month}$ by the end of 2017 as reported by Platt in October 2016. This will mean that the demand for marine gas oil, which is currently about $320,000 \mathrm{mt}$ per month, will have an approximately $50-50$ ratio (if not lower) with the ULSFO. Already there are nine different types of ULSFO available in the markets worldwide, as reported by the Baltic Ports Organisations (BPO) in 2016. However, some ship owners have shown their concern over the unknown effect of using the ULSFO over time on ship engines originally designed for HFO. Lastly, all respondents agreed that the 2020 global sulphur cap is a major "game changer" and there are different speculations on its full impact on fuel demand, which are beyond the scope of this study.

$L N G$ as an alternative fuel: There was a strong promotion of LNG as a marine fuel across Europe and many ship owners would prefer to use it. The use of LNG is not only useful for the compliance of SOx and PM but it also ensures the compliance of the anticipated NOx emissions regulation. Ferries are the largest group of vessels fuelled by LNG. There are 18 ferries powered by the LNG engine, 14 of which are small car/passenger ferries. Others are 4 general cargo ships, 2 ro-ro ships, and 3 gas carriers. From discussions with BPO, there are no containers ships or bulk carries fuelled by LNG. However, because of how expensive it is to retrofit or to install in a newly built ship, out of the 28 ships operating short sea shipping in the European SECA, there are only 3 LNG powered vessels operating in the BSR as shown in Figure 1.

The use of the scrubber: The scrubbers are mostly installed on ferries, ro-ro and general cargo (feeder container) ships. However, the rate at which the fuel price has plummeted in the past three years has somewhat decreased the investment in the scrubber technology, although a few investment cases are still seen. By the end of 2016, 83 ships were equipped with the scrubbers in the European SECA. As shown in Table 3, there are 41 ro-ro and 28 ro-pax vessels retrofitted with the scrubbers. Other retrofitted vessels are: 5 bulk carriers, 5 containers, 3 general cargo ships and 1 tanker. The average age for a scrubber retrofit is 9.5 years. By the end of 2017, more ships are still expected to be scrubber retrofitted with the scrubber. Going by BPO extrapolations, there should be around 200 scrubberretrofitted vessels by 2020 . 
Figure 1. The number of LNG-powered vessels on European SECA

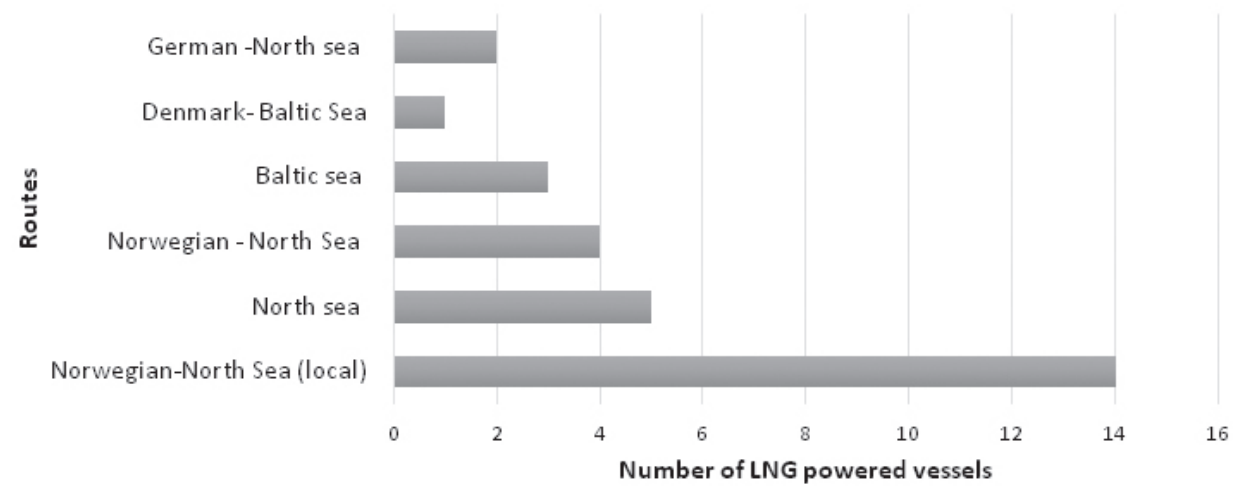

Source: Compiled by the author from multiple sources

From an interview at the Maritime University of Szczecin, Poland, running a scrubber on board ships requires additional $13 \mathrm{MWh}$ electricity per day. This means 80 euros per MWh will mean a 100,000 euros per year additional running costs, notwithstanding the maintenance and extra running fuel costs.

Table 3. Scrubber retrofits in European SECA (ro-ro and ro-pax)

\begin{tabular}{lll}
\hline Shipping lines & Ro/Ro & Ro/Pax \\
\hline DFDS & 15 & 6 \\
Finnlines & 11 & 4 \\
Transfennica & 6 & - \\
KESS & 4 & - \\
Royal Wagenborg & 2 & - \\
P\&O Ferries & 1 & - \\
TransAtlantic & 1 & - \\
Condor Ferries & 1 & 1 \\
Brittany Ferries & - & 6 \\
Color Line & - & 4 \\
Scandlines & - & 4 \\
Stena Line & - & 2 \\
TT-Line & - & 1 \\
\hline Total & $\mathbf{4 1}$ & $\mathbf{2 8}$ \\
\hline
\end{tabular}

Source: Compiled by the author from multiple sources 
Now there are ongoing debates on how safe using the open loop scrubber is to the environment since the exhaust wash water is discharged directly into the seawater and some are calling for its ban in the BSR. Although there are no clear rules on how this should be handled, the hybrid scrubber innovation is widely accepted to solve this dilemma. This way, ship owners can use the closed loop scrubber when on the shallow waters of the BSR and change to the open loop during deep sailing.

\subsubsection{Compliance strategy cases from shipping lines}

Tallink, Estonia: Tallink has 17 vessels - 2 cargo, 6 ro-ro, 9 cruises of which 3 are chartered out. The shipping line uses the MGO. In February 2017, Tallink launched a new ship-The Megastar. The Megastar is a five-engine vessel powered by both the LNG and the MGO

Viking Line, Finland: Viking Line runs 7 vessels. For SECA compliance, the Viking is focusing on LNG-powered vessels. Viking's first LNG-powered ship, The Viking Grace, started operations in 2013 and was the first LNG-powered ship in Europe. Like Tallink, Viking has no scrubber-retrofitted ship.

DFDS Seaways Denmark: DFDS is one of the biggest shipping lines in Europe and has 53 vessels with 5 on a charter. DFDS leverages on the reduction in fuel price and price spread between HFOs and the other distillate oil by investing in the scrubber. Currently, the company has 21 scrubber-retrofitted vessels comprising of 15 ro-ro and 6 ro-pax ships (see Fig. 3).

\subsubsection{Compliance and monitoring activities in the ports}

$L N G$ infrastructures in the ports: The projects of the Baltic Port Organisation, LNG in Baltic Sea Ports and LNG in Baltic Sea Ports II started fostering the development of LNG bunkering in the BSR with the aim of synchronising investment in ports' networks in order to regulate the LNG. This was after the introduction of the EU Directive 2014/94/EU on LNG bunkering infrastructure, spurring a steady growth of the LNG bunkering facilities within the BSR ports. Some ports with limited or no LNG infrastructures offer the boat-boat and truck-ship bunkering. Ports with some sort of LNG bunkering facilities/terminals are the port of Stockholm, Gothenburg, Nynäshamn, Lysekil (Sweden), Świnoujście (Poland), Klaipeda (Lithuania), Pori (Finland) and Hirtshals (Denmark). The Swedish Maritime is arguably at the forefront of clean shipping activities in the EU.

Onshore power supply (OPS): Leaving the auxiliary engine running at the ports has been a major source of noise and emission pollution at the port. The use of OPS ensures significant health benefits for the ship crews as well as for people 
living around the ports because as soon as the ships stop using the fuel-powered engines, the noise from ship vibrations and the emissions from fuel combustion stop. The ports of Gothenburg, Stockholm, Lübeck, Helsinki and Ystad are currently equipped with the OPS.

Compliance monitoring and control: Ports and coastal states are directly responsible for vessels compliance inspections in relation to their nation as well as international law (OECD/ITF, 2016). Compliance monitoring is done through inspections of ships' records especially those of ships without installed emission abatement equipment and fuel samplings. Sniffing devices are strategically stationed at the Great Belt Bridge of Denmark. There are also surveillance aircrafts that measure emissions around the ports. These devices are optical ultraviolet spectroscopic sensors that analyse the concentrated path of $\mathrm{SO}_{2}$ and $\mathrm{NO}_{2}$ from ships. Emissions from at least a 100 ships are monitored every month. The OECD reported that in 2015, according to figures by EMSA, about $2.8 \%$ (427) of the inspected ships $(15,247)$ were found to have defaulted. Nevertheless, by the second half of the year, the non-complaint rate became very low compared to what it was earlier in that year. The Danish shipping (formerly known as Danish Shipowners' Association), confirmed that the noncompliance rate has reduced drastically and that since 2015 , only 19 shipping companies have been reported to default. Two of which were recently reported by the Danish EPA (Environmental Protection Agency) in September 2017. Additionally, from an expert interview with Prof Mellqvist, an EnviSuM partner from Chalmers University based on about 4,000 tests they conducted in the middle of the BSR Sea between 2016 and 2017 there was about 95\% emissions compliance rate and about $85 \%$ compliance around the borders.

\subsection{Study 2: Evaluation of the impact of SECA regulations on maritime business activities in the BSR}

The results from Study 2 are based on the analysis of the administered BSRwide survey responses.

\subsubsection{Stakeholders' familiarity with the SECA regulation}

The procedures used for this study are according to business statistics elucidated by Aczel and Sounderpandian (2002). The stakeholders' responses are expressed in percentages of the overall responses $(n=122)$.

All the respondents answered that they were very familiar with the SECA regulation and about $67 \%$ responded that their employees are fully aware of 
the SECA regulation and have conducted SECA-related training for their staff. Of the stakeholders, 91.7\% monitor and evaluate their clean shipping emission parameters regularly and, surprisingly, while most admitted that this is because it was obligatory, they also admitted to doing so because they care about their ecological footprint (82\%), they wish to benchmark against their competitors $(64 \%)$ and $54.5 \%$ feel that doing so would benefit their company. More than half (about 60\%) indicated their interest in the use of an investment decision tool for SECA-related investments.

When asked about how satisfied they were with the preparation and introduction of SECA regulations in the BSR, $63 \%$ agreed that they were satisfied with the SECA preparations but pointed out that there were some loopholes, such as information gap, underdeveloped services, underdeveloped and unclear rules for sanctions, monitoring and controlling activities. Most respondents feel most strongly about unclear rules for monitoring and sanctions (45.7\%), followed by underdeveloped services and infrastructure (37.1\%). Furthermore, the stakeholders believe that future discussions on SECA should be centred mostly on a "BSR-wide availability of SECA-related services and infrastructure", "use of low sulphur fuel", "technology improved information collaboration" and "the use of LNG". The "scrubber solution" was considered as one of the least important topics by $74.3 \%$ of the respondents.

\subsubsection{Economic impact of SECA regulation-the stakeholders' perspectives}

The mean and standard deviation of the scores on the "economic impact of SECA regulations" data exhibit that nearly all mean (M) for all the variables were close to zero, except for innovation $(M=1.106)$ and branding $(M=0.812)$, suggesting that the evaluation of the SECA impact is comparatively similar among the stakeholders. It also indicates that at two years implementation of SECA, its effect on fiscal measurements such as costs, pricing, FDI, cargo flows and modal splits are perceived as insignificant by the stakeholders. Nevertheless, much impact is expected to be from innovation and branding of the BSR.

In order to find out which of the nine variables have a significant impact on the variable "overall economic impact of SECA", additional regression analysis according to Mendenhall \& Sincich (1989) was used. The F-test indicated a substantial fit for the subsequent model even though the R-squared was 58\%. From the regression analysis coefficients and the related t-test, factors like blue growth, cargo flows and branding were statistically substantial with a positive leading sign of $r=0.56,0.33$ and 0.32 , respectively. Their $\beta$-coefficient percentages also showed that they accounted for about $56 \%$ of the "overall 
economic impact of SECA". This implies that blue growth, cargo flows and the BSR branding/reputation are the most important factors linked to the "overall impact of SECA" and are in parallel with SECA growth. In other words, to improve the general perception on SECA among the stakeholders, emphasis should be on to how to improve stakeholders' opinion on overall, blue growth and branding. Pricing showed as being "nearly significant" having a $p$-value of $8 \%$ but with a negative sign. This negative sign could indicate that an increase in pricing will negatively affect the "overall perception of SECA".

Finally, 1-factor ANOVA was used to test the existence of the differences in the responses from Denmark (DE) and Estonia (EE), because both countries have the highest number of responses. A review of the results showed significant differences in four responses: overall effect, development, blue growth and FDI with probability error of $p<.05$. Overall impact and development have a much lower probability error of $p<.01$. The Danish are six times more positive (mean $=0.8$ ) about the overall impact of SECA regulations when compared to the Estonians (mean $=0.125)$ suggesting a more liberal reception towards SECA regulation and better acceptance from Denmark. Estonians show a neutral disposition towards development and are less positive towards blue growth when compared with their Danish counterparts who are positive on both variables. Again, when it comes to the flow of FDI, the Estonians showed a negative stance while the Danish believe SECA will improve and attract foreign direct investments into the BSR.

\section{Discussions and implications}

The various SECA compliance activities witnessed in the BSR confirm that institutions indeed do have great influence on the sets of actions and behavioural pattern witnessed in the maritime industry and accomplished via new technologies and improved behaviour across all stakeholders in the maritime industry in a combined and cohesive effort of several actions. The principal logic of institutionalism, in this case, shows how institutions influence their members to act in response to the basic elements of the institutional structure although mostly are company-specific strategies.

The first part of this study answered the first question and the results showed major modifications in the way the shipping industry is being operated in the BSR. It also displayed the efforts made by the ports to ensure compliance since SECA regulations came into force in the BSR. Even though the SECA 
regulations make it compulsory for ship owners to use low sulphur fuel, the costs of bunkering have not gone up. In fact, the reverse is the case with ship owners making meaningful savings from the fuel costs, although it might be difficult to predict how long this might last. Furthermore, there have been major overhauling made in the way most shipping line works. Some have changed, reduced or increased their number of routes, while some have replaced their smaller vessels with bigger ones. These strategies made to reduce the economic impact of the SECA regulations could have led to the current overcapacity seen in the shipping industry.

The second question revealed the various innovative actions taken in order to mitigate or reduce the impact of compliance such as the hybrid marine fuel, surveillance drones for monitoring and compliance checks. The scrubber technology especially could be a major source for the obviously needed technology push-effect in the EU but it constitutes huge investment costs and risks for the ship owners. The intensified OPS infrastructures growth in the ports (although not borne out of SECA compliant need), have greatly improved the noise and air quality around the ports. Even at this, the OPS entails an adaptation for appropriate gears like the frequency converters in the ports and on the ships. This is will be additional costs requiring full teamwork for all concerns.

The third question answered from the survey analysis showed that the stakeholders do not really have negative impressions about SECA, neither have they experienced significant instability in their business as a result of its compliance. Unexpectedly, this evaluation was unanimous among the stakeholders. Yet, most respondents agreed that policymakers should have given them more time to prepare for the SECA implement especially when the investment costs and risks are quite high. They insisted that the preparation time would have prevented the dilemma they faced when deciding compliance options and at the same time would have reduced the financial wastage on the limited options available from the onset. An inference from this could be that most of them, especially the ship owners, would have wanted to have links to a reliable source that would ensure their decisions yield better results and make them better advantaged. Interestingly, the results also indicated that the ship owners are not averse to the use of the scrubber but would rather have a scrubber retrofit with an old vessel but install an LNG on their new vessels. This can be attributed to the high costs of LNG retrofit. 


\section{Conclusions}

The purpose of this article was to study the various measures taken in the maritime industry in BSR towards sulphur emission reduction and assess the stakeholders' perception of the economic impact of SECA regulations. All the activities observed are worthwhile contributions to clean shipping and blue growth in the BSR. At the creation of SECA, there were concerns that the regulations would have negative impact on the general maritime sector in BSR. Some of these fears were mostly on the modal shift from the sea to the road, increased costs of sea transportation that will to cascade down to the cost of goods, especially agricultural produce. However, from the reports and results of this study, the effect has not been as intense as was originally anticipated, particularly on ship owners and the ports.

This conclusion highlights the contribution of this work to the body of knowledge. First, it illuminates how various stakeholders have contributed to clean shipping, blue growth and the EU 2020 objectives in the BSR. Second, it serves as a background study for the 2020 global sulphur cap implementation. Third, showcasing the achievements in the BSR maritime industry will put the BSR in a good light that can be used as an accelerator for larger solutions explored worldwide.

A limitation of this study is that it left out fuel prices, an important parameter to capture the impact of the SECA compliance based on its timeline factor. An interesting further research direction could be to capture fuel costs and its historical time series to create an "Investment Decision Tool" accessible to all maritime stakeholders.

Eunice Omolola Olaniyi studied International Business at the University of Salford, Manchester, UK. She is currently an EnviSuM Project Manager and works in the Tallinn University of Technology partner's office in Tallinn, Estonia where she is also a PhD candidate. The EnviSuM project (Environmental Impact of Low Emission Shipping: Measurements and Modelling Strategies) is funded by the European Union and studies the technical efficiency and socio-economic impacts of clean shipping solutions in view of the IMO emission regulations that entered into force in January 2015. 


\section{References}

Abrahamson, E. (1991), 'Managerial fads and fashions: The diffusion and rejection of innovations,' Academy of Management Review, vol. 16, no. 3, pp. 586-612. https://doi.org/10.2307/258919

Aczel, A.D. \& Sounderpandian, J. (2002), Complete Business Statistics, vol. 1, New York: McGraw-Hill/Irwin.

AirClim(2011), Air Pollution from Ships, Air Pollution \& Climate Secretariat, Seas at Risk, Bellona Foundation, North Sea Foundation, Transport \& Environment \& European Environmental Bureau. Retrieved from https:/www.transportenvironment.org/ publications/air-pollution-ships-0 [accessed 9 Sep 2016]

Alcamo, J.; Amann, M.; Hettelingh, J. P.; Holmberg, M.; Hordijk, L.; Kämäri, J.; Kauppi, L.; Kauppi, P.; Kornai, G. \& Mäkelä, A. (1987), 'Acidification in Europe: a simulation model for evaluating control strategies,' Ambio, vol. 16, no. 5, pp. 232-245.

Atari, S. \& Prause, G. (2017, forthcoming), 'Risk assessment of emission abatement technologies for clean shipping,' in Proceedings of the 17th International Conference "Reliability and Statistics in Transportation and Communication" (RelSTat2017 Conference), Riga.

Bergqvist, R.; Turesson, M. \& Weddmark, A. (2015), 'Sulphur emission control areas and transport strategies - the case of Sweden and the forest industry,' European Transport Research Review, vol. 7, no. 2, pp. 1-15. https://doi.org/10.1007/s12544-015-0161-9

Breitzmann, K. H.; Möller, M. \& Wenske, C. (2013), 'Baltic maritime transport, its structure, competitive situation and economic weight,' in K. Breitzmann \& M.Hytti (eds.) Pan-Baltic Manual of Best Practices on Clean Shipping and Port Operations, Turku: UBC Environment and Sustainable Development Secretariat.

Brynolf, S.; Magnusson, M.; Fridell, E. \& Andersson, K. (2014), 'Compliance possibilities for the future ECA regulations through the use of abatement technologies or change of fuels,' Transportation Research Part D: Transport and Environment, vol. 28, pp. 6-18. https://doi.org/10.1016/j.trd.2013.12.001

Cofala, J.; Amann, M.; Heyes, C.; Wagner, F.; Klimont, Z.; Posch, M. \& Stavrakaki, A. (2007), Analysis of policy measures to reduce ship emissions in the context of the revision of the national emissions ceilings directive, Final Report, IIASA Contract 06-107, Laxenburg: International Institute for Applied Systems Analysis.

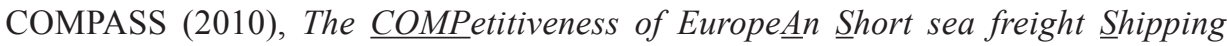
compared with road and rail transport, Final Report, European Commission DG Environment Transport \& Mobility Leuven, 18 August 2010. 
Concawe (2006), Techno-economic analysis of the impact of the reduction of sulphur content of residual marine fuels in Europe, Concawe Report 2/06, Brussels. (2013), Oil refining in the EU in 2020, with perspectives to 2030. The oil companies' European association for Environment, Health and Safety in refining and distribution, Concawe Report 1/13R, Brussels.

Corbett, J. (2007), 'Mortality from ship emissions: A global assessment,' Environmental Science and Technology, vol. 41, no. 24, pp. 8512-8518.

https://doi.org/10.1021/es071686z

Corbett, J. J. \& Farrell, A. (2002), 'Mitigating air pollution impacts of passenger ferries,' Transportation Research Part D: Transport and Environment, vol. 7, no. 3, pp. 197-211. https://doi.org/10.1016/S1361-9209(01)00019-0

Cullinane, K. R. \& Bergqvist, R. (2014), 'Emission control areas and their impact on maritime transport,' Transportation Research Part D, vol. 28, pp. 1-5. https://doi.org/10.1016/j.trd.2013.12.004

Dacin, M. T.; Goodstein, J. \& Scott, W. R. (2002), 'Institutional theory and institutional change: Introduction to the special research forum,' Academy of Management Journal, vol. 45, no. 1, pp. 45-56. https://doi.org/10.5465/AMJ.2002.6283388

Daduna, J.; Hunke, K. \& Prause, G. (2012), 'Analysis of short sea shipping-based logistics corridors in the Baltic Sea region,' Journal of Shipping and Ocean Engineering, vol. 2, no. 5, pp. 304-319.

Daduna, J. \& Prause, G. (2016), 'The Baltic Sea as a maritime highway in international multimodal transport,' in Proceedings of the International Conference on Operations Research OR 2015: Optimal Decisions and Big Data”, 1-4 September 2015, Vienna $(X-X)$, Berlin: Springer-Verlag.

DiMaggio, P. \& Powell, W. (1983), 'The iron cage revisited: Institutional isomorphism and collective rationality in organizational fields,' American Sociological Review, vol. 48, no. 2, pp. 147-160. https://doi.org/10.2307/2095101

Easterby-Smith, M.; Thorpe, R. \& Jackson, P. (2012), Management Research, 4th ed., Thousand Oaks \& London: SAGE Publications.

Ecofys (2015), Potential for shore side electricity in Europe, Ecofys Final Report, Commissioned by European Commision DG Clima, Utrecht, Netherlands.

EU (2010), EUROPE 2020: A European Strategy for Smart, Sustainable and Inclusive Growth. Retrieved from http://ec.europa.eu/eu2020/EuropeENversion.pdf [accessed 20 May 2017]

- (2012), Europe 2020: Europe's growth strategy: Growing to a sustainable and job-rich future. Retrieved from http://ec.europa.eu/europe2020/pdf/europe_2020_ explained.pdf [accessed 20 May 2017]

Fowler, F. J. Jr (1995), Improving Survey Questions: Design and Evaluation, Thousand Oaks: SAGE Publications. 
Furusten, S. (2013), Institutional Theory and Organizational Change, Cheltenham: Edward Elgar Publishing. https://doi.org/10.4337/9781782547099

Gardberg, N. A. \& Fombrun, C. J. (2006), 'Corporate citizenship: Creating intangible assets across institutional environments,' Academy of Management Review, vol. 31, no. 2, pp. 329-346. https://doi.org/10.5465/AMR.2006.20208684

Gros, D. \& Roth, F. (2012), The Europe 2020 Strategy: Can it maintain the EU'S competitiveness in the world? Brussels: Centre for European Policy Studies (CEPS).

Hämäläinen, E. (2015), 'Estimated impacts of the sulphur directive on the Nordic industry,' European Transport Research Review, vol. 7, no. 8. https://doi. org/10.1007/s12544-015-0158-4

Hämäläinen, E.; Hilmola, O. P. \& Tolli, A. (2016), 'North European export industry and the shadows of sulphur directive,' Transport and Telecommunication Journal, vol. 17, no. 1, pp. 9-17.

Helcom (2012), Maritime Activities in the Baltic Sea, Baltic Sea Environment Proceedings, no. 123. Retrieved from https:/www.google.ee/search?q=helocme + report $+\&$ ie $=$ utf. [accessed 20 Dec 2016]

Holmgren, J.; Nikopoulou, Z.; Ramstedt, L. \& Woxenius, J. (2014), 'Modelling modal choice effects of regulation on low-sulphur marine fuels in Northern Europe,' Transportation Research Part D: Transport and Environment, vol. 28, pp. 62-73. https://doi.org/10.1016/j.trd.2013.12.009

Hunke, K. \& Prause, G. (2013), 'Management of green corridor performance,' Transport and Telecommunication, vol. 14, no. 4, pp. 292-299. https://doi. org/10.2478/ttj-2013-0025

IMO (2008), Revised MARPOL Annex VI: Regulations for the prevention of air pollution from ships and NOx technical code, London: IMO Marine Environmental Protection Committee (MEPC).

(2009), Prevention of air pollution from ships, Second IMO GHG Study 2009. Update of the 2000 IMO GHG Study Final report covering Phase 1 and Phase 2: noted by Secretariat (MEPC 59/INF.10), London: IMO Marine Environmental Protection Committee (MEPC).

(2013), Sulphur oxides (SOx) - Regulation 14. Retrieved from http://www.imo. org/OurWork/Environment/PollutionPrevention/AirPollution/Pages/Sulphuroxides-(SOx)- Regulation-14.aspx [accessed 20 Sep 2016]

(2015), Guidance on the application of regulation 13 of MARPOL annex VI tier III requirements to dual fuel and gas-fuelled engines. MEPC.1/Circ.854, London: IMO Marine Environmental Protection Committee (MEPC).

— (2016), 'IMO sets 2020 date for ships to comply with low sulphur fuel oil requirement, Press briefing release, 28 October 2016. Retrieved from http://www. imo.org/en/MediaCentre/PressBriefings/Pages/MEPC-70-2020sulphur.aspx [accessed 30 Nov 2016] 
Jiang, L.; Kronbak, J. \& Christensen, L. P. (2014), 'The costs and benefits of sulphur reduction measures: Sulphur scrubbers versus marine gas oil,' Transportation Research Part D, vol. 28, pp. 19-27. https://doi.org/10.1016/j.trd.2013.12.005

Kerlinger, F. (1986), Foundations of Behavioral Research, 3rd ed., New York: CBS College Publishing.

Korhonen, J.; Pätäri, S.; Toppinen, A. \& Tuppura, A. (2015), 'The role of environmental regulation in the future competitiveness of the pulp and paper industry: the case of the sulphur emissions directive in Northern Europe,' Journal of Cleaner Production, vol. 108, pp. 864-872. https://doi.org/10.1016/j. jclepro.2015.06.003

Kostova, T. \& Roth, K. (2002), 'Adoption of an organizational practice by subsidiaries of multinational corporations: Institutional and relational effects,' Academy of Management Journal, vol. 45, no. 1, pp. 215-233. https://doi.org/10.2307/3069293

Leary, Z. (2009), The Essential Guide to Doing Your Research Project, Los Angeles \& London: SAGE Publications.

Lieberman, M. B. \& Asaba, S. (2006), 'Why do firms imitate each other?' Academy of Management Review, vol. 31, no. 2, pp. 366-385. https://doi.org/10.5465/ AMR.2006.20208686

Martin, J. \& Frost, P. (1996), 'Organizational culture war games: a struggle for intellectual dominance,' in S. R. Clegg, C. Hardy \& W. R. Nord (eds.) Handbook of Organization Studies, London: SAGE Publications.

Martin, R. \& Sunley, P. (1998), 'Slow convergence? The new endogenous growth theory and regional development,' Economic Geography, vol. 74, no. 3, pp. 201227. https://doi.org/10.2307/144374

Mellqvist, J. (2016), SOx Compliance Monitoring, EnviSuM Partner Meeting, 26 October 2016, Copenhagen.

Mendenhall, W. \& Sincich, T. (1989), A Second Course in Business Statistics: Regression Analysis, Basingstoke: Macmillan Publishing.

Meyer, J. W. (2008), 'Reflections on institutional theories of organizations,' The Sage Handbook of Organizational Institutionalism, London \& Thousand Oaks: SAGE Publications, pp. 790-811. https://doi.org/10.4135/9781849200387.n35

Meyer, J. W. \& Rowan, B. (1977), 'Institutionalized organizations: Formal structure as myth and ceremony,' American Journal of Sociology, vol. 83, no. 2, pp. 340-363. https://doi.org/10.1086/226550

Nabielek, K.; Hamers, D. \& Evers, D. (2016), 'Smart, green and inclusive urban growth: visualising recent developments in European cities,' In REAL CORP 2016-SMART ME UP! How to become and how to stay a Smart City, and does this improve quality of life? Proceedings of 21st International Conference on Urban Planning, Regional Development and Information Society, CORP: Competence Center of Urban and Regional Planning, pp. 953-957. 
North (2016), China: Emission Control Areas. Retrieved from http://www.nepia.com/ news/industry-news/china-emission-control-areas-starupdatestar/. [accessed 22 Dec 2016]

Notteboom, T. (2010), 'The impact of low sulphur fuel requirements in shipping on the competitiveness of roro shipping in Northern Europe,' WMU Journal of Maritime Affairs, vol. 10, no. 1, pp. 63-95. https://doi.org/10.1007/s13437-010-0001-7

NSF (2008), Clean Shipping: Towards an integrated approach of sustainable shipping, Utrecht: North Sea Foundation.

Nugraha, F. 2009. Effective implementation of emission control area towards cleaner shipping operations: focusing on sulphur oxides (SOx) emission reduction, World Maritime University Dissertations, 186.

OECD/ITF (2016), Reducing Sulphur Emissions from Ships: The Impact of International Regulation. Retrieved from http://www.itf-oecd.org/reducing-sulphur-emissionsships-impact-international-regulation [accessed 10 Jun 2016]

Olaniyi, E. O. \& Prause, G. K. (2016), 'Baltic-Russian innovation cooperation in the context of EU Eastern Partnership,' in T. Kerikmäe \& A. Chochia (eds.) Political and Legal Perspectives of the EU Eastern Partnership Policy, Cham: Springer International Publishing, pp. 257-279.

Olaniyi, E. O. \& Viirmäe, M. (2016), 'The economic impact of environmental regulations on a maritime fuel production company,' Research in Economics and Business: Central and Eastern Europe, vol. 8, no. 2, pp. 58-84.

Panagakos, G. P.; Stamatopoulou, E. V. \& Psaraftis, H. N. (2014), 'The possible designation of the Mediterranean Sea as a SECA: A case study,' Transportation Research Part D: Transport and Environment, vol. 28, pp. 74-90. https://doi. org/10.1016/j.trd.2013.12.010

Peters, B. G. (2000), Institutional Theory: Problems and Prospects, Political Science Series, Dissertation of Department of Political Science, Institute for Advanced Studies (IHS).

Prause, G. (2014a), 'Smart specialization and EU eastern innovation cooperation: a conceptual approach,' Baltic Journal of European Studies, vol. 4, no. 1, pp. 3-19. https://doi.org/10.2478/bjes-2014-0001

(2014b), 'Sustainable development of logistics clusters in green transport corridors,' Journal of Security and Sustainability Issues, vol. 4, no. 1, pp. 59-68. https://doi.org/10.9770/jssi.2014.4.1(5)

Prause, G. \& Hunke, K. (2014), 'Sustainable entrepreneurship along green corridors,' Journal of Entrepreneurship and Sustainability Issues, vol. 1, no. 3, pp. 124-133. https://doi.org/10.9770/jssi.2014.1.3(1)

Reynolds, L. (1981), 'Foundations of an institutional theory of regulation,' Journal of Economic Issues, vol. 15, no. 3, pp. 641-656. https://doi.org/10.1080/00213624. 1981.11503881 
SHEBA (2014), Sustainable Shipping and Environment of the Baltic Sea Region. Retrieved from http://www.bonusprojects.org/bonusprojects/the_projects/ sustainable_ecosystem_projects/sheba [accessed 30 Jun 16]

Stipa, T. (2013), 'Clean shipping current,' in K. Breitzmann \& M. Hytti (eds.) PanBaltic Manual of Best Practices on Clean Shipping and Port Operations, Turku: UBC Environment and Sustainable Development Secretariat.

Tolbert, P. S. \& Zucker, L. G. (1983), 'Institutional sources of change in the formal structure of organizations: The diffusion of civil service reform, 1880-1935,' Administrative Science Quarterly, pp. 22-39. https://doi.org/10.2307/2392383

Wiśnicki, B.; Czermański, E.; Droździecki, S.; Matczak, M. \& Spangenberg, E. (2014), Sulphur Regulation-technology solutions and economic consequences for the Baltic Sea Region shipping market, Gdansk: Institute of Maritime Transport and Seaborne Trade, University of Gdańsk.

Zucker, L. G. (1987), 'Institutional theories of organization,' Annual Review of Sociology, vol. 13, no. 1, pp. 443-464. https://doi.org/10.1146/annurev.so.13.080187.002303 